This document is the accepted manuscript version of the following article: Rüegg, J., Quezada, J. C., Santonja, M., Ghazou1, J., Kuzyakov, Y., Butt1er, A., \& Guillaume, T. (2019). Drivers of soil carbon stabilization in oil palm plantations. Land Degradation and Development, 30(16), 1904-1915. https://doi.org/10.1002/1dr.3380

\title{
1 TITLE: Drivers of soil carbon stabilization in oil palm plantations
}

2

3 RUNNING TITLE: Soil carbon stabilization in oil palm plantations

4

5 AUthors: Johanna Rüegg ${ }^{1,2}$, Juan Carlos Quezada ${ }^{1,3}$, Mathieu Santonja ${ }^{1,3,4}$, Jaboury 6 Ghazoul $^{2}$, Yakov Kuzyakov ${ }^{5,6,7}$, Alexandre Buttler ${ }^{1,3,8}$, Thomas Guillaume ${ }^{1,3}$

\section{ADDRESSES}

$9{ }^{1}$ École Polytechnique Fédérale de Lausanne EPFL, School of Architecture, Civil and 10 Environmental Engineering ENAC, Laboratory of ecological systems ECOS, 1015 Lausanne, Switzerland.

${ }^{2}$ Chair of Ecosystem Management, Institute of Terrestrial Ecosystems, Department of Environmental Systems Science, ETHZ, 8092 Zürich.

${ }^{3}$ Swiss Federal Institute for Forest, Snow and Landscape Research WSL, Site Lausanne, 1015 Lausanne, Switzerland.

${ }^{4}$ Aix Marseille Univ, Avignon Université, CNRS, IRD, IMBE, Marseille, France.

${ }^{5}$ Georg August University, Department of Soil Science of Temperate Ecosystems, Agricultural Soil Science, 37077 Göttingen, Germany.

${ }^{6}$ Institute of Environmental Sciences, Kazan Federal University, 420049 Kazan, Russia.

${ }^{7}$ Institute of Physicochemical and Biological Problems in Soil Science, Russian Academy of Sciences, 142290 Pushchino, Russia.

${ }^{8}$ Laboratoire de Chrono-Environnement, UMR CNRS 6249, UFR des Sciences et Techniques,

CORRESPONDING AUTHOR: Thomas Guillaume (thomas.guillaume@epfl.ch) 
27 Increasing soil organic carbon (SOC) in agroecosystems is necessary to mitigate climate change and soil degradation. Management practices designed to reach this goal call for a deeper understanding of the processes and drivers of soil carbon input stabilization. We identified main drivers of SOC stabilization in oil palm plantations using the well-defined spatial patterns of nutrients and litter application resulting from the usual management scheme. The stabilization of oil palm-derived SOC (OP-SOC) was quantified by $\delta^{13} \mathrm{C}$ from a shift of C4 (savanna) to C3 (oil palm) vegetations. Soil organic carbon stocks under frond piles were 20 and $22 \%$ higher compared to harvest paths and interzones, respectively. Fertilization and frond stacking did not influence the decomposition of savanna-derived SOC. Depending on management zones, net OP-SOC stabilization equalled 16-27\% of the fine root biomass accumulated for 9 years. This fraction was similar between frond piles and litter-free interzones, where mineral NPK fertilization is identical, indicating that carbon inputs from dead fronds did not stabilize in SOC. A path analysis confirmed that the OP-SOC distribution was largely explained by the distribution of oil palm fine roots, which itself depended on management practices. SOC mineralization was proportional to SOC content and was independent on phosphorus availability. We conclude that SOC stabilization was driven by C inputs from fine roots and was independent of alteration of SOC mineralization due to management. Practices favouring root growth of oil palms would increase carbon sequestration in soils without necessarily relying on the limited supply of organic residues.

47 KEYWORDS: carbon isotopes - fertilization - fine roots - microbial activity - structural equation modelling - savanna - Colombia 


\section{INTRODUCTION}

Soil organic carbon (SOC) depletion in agroecosystems is a major source of greenhouse gas emissions, resulting in losses of soil fertility and ecosystem stability (Amundson et al., 2015). Policymakers have recently acknowledged the promotion of soil $\mathrm{C}$ sequestration in agroecosystems as a promising strategy to simultaneously mitigate climate change and enhance food security (Lal, 2016). Nonetheless, management practices favouring soil C sequestration lead to highly variable outcomes, calling for a deeper understanding of processes and factors controlling C stabilization, especially after land-use changes (Ghimire, Lamichhane, Acharya, Bista, \& Sainju, 2017; Haddaway et al., 2017). This is particularly needed in regions that are undergoing rapid and substantial land degradation following conversion from largely forested landscapes to intensive agricultural systems, as has been the case in tropical landscapes dominated by oil palm (Elaeis guineensis) plantations. In Sumatra, a region with a long history of oil palm cultivation, a significant proportion of oil palm plantations has already reached a critical low level of SOC content $(<1 \%)$ in the topsoil (Guillaume, Holtkamp, Damris, Brümmer, \& Kuzyakov, 2016).

Stocks of SOC depend on the balance between soil C inputs from vegetation and outputs from SOC mineralization, erosion and leaching (Lorenz \& Lal, 2018). This balance is strongly affected by the conversion of natural ecosystems to intensive agricultural land (Guillaume et al., 2018). Predicting impacts of land-use change and management on SOC dynamics and its stabilization faces major difficulties as many factors affect both litter input and mineralization processes that determine the fraction of $\mathrm{C}$ input stabilized in SOC. While higher plant biomass inputs might lead to higher SOC accumulation, an increase of fresh organic matter inputs may enhance the mineralization of more recalcitrant SOC that ultimately reduces the gain in SOC, a process known as priming (Kuzyakov, Friedel, \& Stahr, 2000). Nutrient application modifies the stoichiometry of organic matter inputs and of soil organic matter, which in turn 
affects microbial processes controlling SOC stabilization (Qiao et al., 2016; Zang, Wang, \& Kuzyakov, 2016). For instance, altered microbial carbon use efficiency (i.e. the ratio of C incorporated into microbial biomass to the added C) or mining for nutrients from recalcitrant SOC result in either SOC gains or losses (Finn et al., 2016; Kirkby et al., 2014). Quantifying soil $\mathrm{C}$ inputs remains a methodological challenge and few data are available, for instance, on root turnover, rhizodeposition, and the fraction of aboveground litter $\mathrm{C}$ stabilized in SOC (Pausch \& Kuzyakov, 2018). Experimental data are especially limited for perennial plants in tropics and subtropics.

The fast SOC turnover in the tropics makes soils particularly sensitive to land-use change (Guillaume, Damris, \& Kuzyakov, 2015; Pabst, Gerschlauer, Kiese, \& Kuzyakov, 2016; Zech et al., 1997). For example, soil C inputs decrease up to $90 \%$ when rainforests are converted to oil palm plantations, resulting in a rapid drop of SOC (Guillaume et al., 2018). Soil organic $\mathrm{C}$ losses are not, however, uniform within plantations, and specific management zones within the plantation may even exhibit a gain in SOC (Khasanah, van Noordwijk, Ningsih, \& Rahayu, 2015; Rahman et al., 2018). Soil C inputs in mature oil palm plantations without cover crops (the most common practice) occurs mostly belowground through rhizodeposition because the understorey is frequently cleared. Significant aboveground C inputs occur only under frond piles, i.e. zones where dead fronds are stacked. A gradient of fertilizer application is superimposed on the gradient of soil $\mathrm{C}$ input: most fertilizers are applied around the trunks and, in some cases, additionally to the whole surface area at lower rate, including the frond piles but excluding the harvest path. These management practises lead to characteristic management zones with specific factors affecting SOC dynamics (Fig 1a). With plantation ageing, the heterogeneity of SOC distribution increases, depending on the distance to the tree, the presence of frond piles and fertilizer applications (Frazão, Paustian, Pellegrino Cerri, \& Cerri, 2013; Goodrick et al., 2015). Carbon and nutrients cycling 
are, thus, highly heterogeneous leading to a variable SOC equilibrium depending on management practices. This highlights the possibility to promote the increase of overall SOC stocks by redesigning management practices to reach this goal.

In Colombia, oil palm plantations are often established on native savanna grasslands dominated by grasses with a $\mathrm{C} 4$ photosynthesis pathway. The shift from $\mathrm{C} 4$ (grasses) to $\mathrm{C} 3$ vegetation (oil palm) allows source determination in soil organic matter using its $\delta^{13} \mathrm{C}$ signature (Balesdent \& Mariotti, 1987). The aim of the present study is to disentangle the effects of soil C and nutrient inputs on newly accumulated SOC (oil palm-derived) and the decomposition of old SOC (savanna-derived), taking advantage of the specific patterns of fertilization and soil $\mathrm{C}$ inputs in the four management zones. We hypothesized that soil $\mathrm{C}$ inputs and consequent SOC accumulation increase with fine root density, which itself depends on plantation age and distance to trees, as well as on the presence of frond piles. Fertilizer application is, however, expected to decrease SOC stabilization rates where soil C inputs are low. Hence, the specific aims of the study are to i) quantify the new oil palm-derived (C3 signature) and the old savanna-derived SOC stocks (C4) in a mature oil palm plantation established on native savanna grassland, ii) assess oil palm root development and its impact on SOC accumulation with plantation age, iii) determine the impacts of management practices on root development and soil microbial activity and iv) identify the main factors (root density, nutrient availability, microbial activity) driving SOC stabilization.

\section{MATERIALS AND METHODS}

\subsection{Study area}

123 The study was conducted in the Eastern Plains (Llanos Orientales), Department Meta, 124 Colombia $\left(4^{\circ} 05^{\prime} 7.0^{\prime \prime} \mathrm{N}, 71^{\circ} 53^{\prime} 59.0^{\prime \prime} \mathrm{W}\right)$. The region experiences a tropical climate (mean 
annual temperature of $26{ }^{\circ} \mathrm{C}$ and yearly precipitation of $2200 \mathrm{~mm} \mathrm{yr}^{-1}$ ) with a distinct dry season from December to March and $95 \%$ of the yearly rain falling between April and November (Lavelle et al., 2014; Rippstein, Amézquita, Escobar, \& Grollier, 2001). The study site lies in the slightly undulating well-drained high plains (Altillanura plana) dominated by Plinthosols and Ferralsols (IUSS Working Group WRB, 2014). These soils have a low fertility, high acidity and high aluminium saturation limiting agricultural production (Lavelle et al., 2014; Rippstein et al., 2001). The natural vegetation is an herbaceous savanna with scarce bushes, which is drained by many small rivers. Gallery forests (morichales) grow in the depressions along these rivers (Rippstein et al., 2001).

Two unmanaged native savanna sites and three oil palm plantations with increasing age (2-, 4-, and 9-year old) were selected within an area of approximately $8 \times 8 \mathrm{~km}$ and sampled in July and August 2016 (Fig. S1). Sites were carefully chosen with the help of plantation agronomists to ensure that the investigated plantations had been established on unmanaged native savannas, i.e. no cattle grazing in the past. Soils in the five selected sites were classified as sandy-loam Ferralsols (clay content and $\mathrm{pH}$ ranging from 11 to $16 \%$ and from 4.5 to 5.3 in the top $30 \mathrm{~cm}$, respectively) with compacted top soil (bulk density ranging from 1.31 to 1.46 $\mathrm{g} \mathrm{cm}^{-3}$ in the top $10 \mathrm{~cm}$ ). Drivers of SOC stabilization were assessed in the 9-year old plantation. The 2- and 4-year old plantations were selected to assess the development of oil palm rooting system and its relationship with SOC accumulation.

\subsection{Plantation management}

146 Oil palm plantations had been established on native savannas whose soils were first loosened

147 with a chisel plough (to a depth of $40 \mathrm{~cm}$ ) and tilled with an overturning plough $(10 \mathrm{~cm})$.

148 Liming and phosphate rocks were applied before planting palms. Oil palm trees had been 149 planted in a triangular grid pattern with a distance of $9 \mathrm{~m}$ between trees, leading to 143 palms 

phaseoloides) and Desmodium (Desmodium heterocarpon subsp. ovalifolium) cover crops

152 (C3 vegetation) have been implemented after planting. Cover crops were never used in the mature plantation (9 years), and in this case the soil was always kept bare after planting with oil palms. Accordingly, C3-derived SOC in the 9-year old plantation are attributed solely to oil palm-derived SOC.

Oil palm management leads to four well-defined management zones in productive plantations (about 4 years after establishment). In the study region, the weeded circle (WC) around the oil palm trunk is always kept free of vegetation (Fig. 1). At young ages (2- and 4year old), all fertilizers are applied in WC. Associated with the beginning of harvest after 4 years, pruning starts and fronds are piled up in between palm trees (frond pile, FP). Each second avenue between palm lines becomes a harvest path (HP), where machines circulate. In productive plantations (after 4 years), fertilizers are evenly spread from the harvest path by machines, i.e. all management zone receive the same amount of fertilizers except the harvest path that receive none. The remaining area, especially the alternating avenue, represents the fourth zone, where the soil is kept bare and fertilization starts after 4 years (interzone, IZ). The relative surface area of the four management zones were $60 \%$ (IZ), $18 \%$ (HP), $12 \%$ (WC) and $10 \%$ (FP). Fertilization depends on oil palm stand age. The 9-year old plantation received per hectare during the first year about $240 \mathrm{~kg}$ of NPK, $60 \mathrm{~kg}$ of kieserite $\left(\mathrm{MgSO}_{4}\right)$, and $25 \mathrm{~kg}$ of $\mathrm{KCl}$, of zinc and of boron. The amount of NPK increased over time while the use of other types of fertilizer varied from year to year. The year before sampling, $600 \mathrm{~kg}$ of NPK, $200 \mathrm{~kg}$ of phosphate rocks and $160 \mathrm{~kg}$ of $\mathrm{KCl}-\mathrm{MgO}$ per hectare were spread in the plantation.

\subsection{Soil and roots sampling}


174 Plots of 1 ha were established in all plantations and savannas in areas with homogeneous soil,

175 far from the influence of roads, rivers or groundwater, free of laterite formations (arecife) and

176 without former amendment of compost or residues from processing oil mills. Five trees as

177 replicates for management zones were selected randomly in each plantation. For each of the

178 five replicate of trees, the adjacent management zones (FP, HP, IZ, and WC) were sampled

179 on a systematic grid (Fig. 1). Frond piles, harvest paths and interzones were sampled at the

180 same distance from trees $(4.5 \mathrm{~m})$ to assess the effects of management starting 4 years after

181 establishment. Two additional points in the interzone were sampled at 2 and $3 \mathrm{~m}$ away from

182 the trunk to assess the horizontal expansion of oil palm roots (IZ2, IZ3, Fig. 1). In the 2- and

183 4-year old plantations, only the weeded circles and interzones were sampled because of the

184 absence of frond piles and harvest path in young plantations. In the 2-year old plantation, the

185 point IZ3 was not sampled, as root densities were already low in IZ2 (Fig. S2). In the savanna

186 plots, five sampling points were selected at regular distances along a $100 \mathrm{~m}$ transect.

Roots and soils were sampled with a cylindrical corer of $5 \mathrm{~cm}$ diameter at three depth intervals $(0-10,10-20$ and 20-30 cm). Roots were separated from soil by sieving at $2 \mathrm{~mm}$ and

189 rinsed to remove attached mineral particles. Fine roots that passed through the sieve were manually picked. For the 2- and 4-year old plantations outside of weeded circles, cover crop roots were removed from oil palm roots. Oil palm roots were divided into coarse roots $(>2$ $\mathrm{mm}$, corresponding to primary and secondary roots of oil palms $)$ and fine roots $(<2 \mathrm{~mm}$, corresponding to tertiary and quaternary roots of oil palms). Dry root biomass was determined

194 after drying at $60{ }^{\circ} \mathrm{C}$ for $48 \mathrm{~h}$. Soil samples were air-dried and sieved at $2 \mathrm{~mm}$ directly after collection and further oven dried at $40{ }^{\circ} \mathrm{C}$ for $48 \mathrm{~h}$ prior to laboratory analyses.

\subsection{Soil analysis}


198 Total $\mathrm{C}$ and nitrogen $(\mathrm{N})$ contents in soil, as well as $\delta^{13} \mathrm{C}$ signature were determined at the 199 University of Göttingen with an isotope ratio mass spectrometer (Delta Plus, Finnigan MAT, 200 Bremen, Germany). Because of the absence of carbonates in acidic soils, total C represents 201 organic C. Residual water content was assessed by drying soil samples at $105{ }^{\circ} \mathrm{C}$ for $24 \mathrm{~h}$. 202 Bulk density was measured by inserting horizontally two cylinders of $100 \mathrm{~cm}^{3}$ per depth at 0 $2035,5-10,10-20$ and $20-30 \mathrm{~cm}$ depth in a soil pit located at the centre of each sampling plot. 204 Bulk density in each cylinder was determined after drying at $105{ }^{\circ} \mathrm{C}$ and averaged between 205 four cylinders for 0-10 cm depth interval and 2 cylinders for 10-20 and 20-30 cm depth 206 intervals. Carbon stocks were calculated multiplying C contents with bulk density and the 207 layer thickness and the respective fractions of C4 (savanna-derived C) and C3 (oil palm208 derived) SOC. Soil available phosphorous (P) was determined using Bray II extraction method (Bray \& Kurtz, 1945). Three grams of soil were extracted by shaking for 15 min with $20 \mathrm{ml}$ of $0.03 \mathrm{~N} \mathrm{NH}_{4} \mathrm{~F}$ and $0.025 \mathrm{~N} \mathrm{HCl}$. Filtered extracts were mixed with a colorimetric reagent $\left(\left(\mathrm{NH}_{4}\right)_{6} \mathrm{Mo}_{7} \mathrm{O}_{24}-\mathrm{SnCl}_{2}\right)$ and absorbance was measured with a UV/VIS spectrometer at $660 \mathrm{~nm}$ (Lambda 35, Perkin Elmer, Buckinghamshire, United Kingdom).

\subsection{C3 and C4 derived carbon}

Relative portion of oil palm- and savanna-derived C in SOC were calculated based on the differences in $\delta^{13} \mathrm{C}$ signature of biomass between savanna grassland, dominated by $\mathrm{C} 4$

217 photosynthetic pathway, and oil palms, C3 photosynthetic pathway, using two sources linear 218 isotopic mixing model (Balesdent \& Mariotti, 1987):

$$
f_{O P_{-} d}=\frac{\delta^{13} C_{S_{\_} d}-\delta^{13} C_{N S_{-} d}}{\delta^{13} C_{O P_{-} b}-\delta^{13} C_{N S_{-} b}}
$$

where $f_{O P \_d}$ is the fraction of oil palm $(\mathrm{C} 3)$-derived SOC, $\delta^{13} \mathrm{C}_{\mathrm{S}_{\mathrm{d}} \mathrm{d}}$ is the isotopic signature measured in a soil sample at depth $\mathrm{d}, \delta^{13} \mathrm{C}_{\mathrm{NS} \_\mathrm{d}}$ is the average isotopic signature at the 
222 corresponding depth in natural savanna reference sites, $\delta^{13} \mathrm{C}_{\mathrm{OP} \_\mathrm{b}}$ is the averaged signature of 223 oil palm fine roots in the mature oil palm plantation (mean $=-28.2 \%$, standard deviation (SD)

$224=0.18, \mathrm{n}=9)$ and $\delta^{13} \mathrm{C}_{\mathrm{NS} \_\mathrm{b}}$ is the average isotopic signature of the aboveground and 225 belowground savanna biomass determined on representative subsamples of aboveground 226 biomass collected on $1 \mathrm{~m}^{2}$ and fine roots collected with soil cores at each sampling point 227 (mean $=-13.6 \%, \mathrm{SD}=1.1, \mathrm{n}=19)$. This approach assumes that the ${ }^{13} \mathrm{C}$ fractionation 228 occurring during the integration of biomass into SOC at each soil depth is the same for savanna and oil palm biomass (Pausch \& Kuzyakov, 2012). No ${ }^{13} \mathrm{C}$ fractionation was observed between savanna plant biomass and savanna SOC in $0-10 \mathrm{~cm}$ layer $(-13.7 \%$, $\mathrm{SD}=$ $2310.5, \mathrm{n}=10)$.

\subsection{Carbon stabilization per cumulative standing root biomass}

234 Fine root stocks served as a proxy for the $\mathrm{C}$ input from oil palm roots. To account for differences in root stocks between management zones and root development time depending on the distance to the palm tree, cumulative standing fine root biomass in each management zone was estimated by fitting a linear model on root biomass measured in various plantation ages. The model was integrated starting from plantation establishment for WC, but only starting from 4 years for IZ, FP and HP, i.e. when oil palm rooting system reached $4.5 \mathrm{~m}$ away from the tree (Fig. S2). Assuming constant belowground C input per unit of fine roots (Pausch,

241 Tian, Riederer, \& Kuzyakov, 2013), oil palm-derived SOC stocks were normalized per unit 242 of cumulated fine root biomass to assess the effect of management zones on net C3 stabilization efficiency.

\subsection{Soil incubation}


Microbial biomass was analysed after incubation of topsoils $(0-10 \mathrm{~cm})$ from the 9-year old plantation (zones FP, HP, IZ and WC). Twenty grams of dry soil were rewetted to $60 \%$ WHC and incubated at $25{ }^{\circ} \mathrm{C}$ for 31 days. Jars were ventilated and weighed every week and rewetted once to compensate for the evaporated water. Carbon and nitrogen $(\mathrm{N})$ in microbial biomass were measured at the end of the incubation by the fumigation-extraction method (Vance et al., 1987). For $\mathrm{C}$ and $\mathrm{N}$ contents, $5 \mathrm{~g}$ of incubated soil were fumigated for $24 \mathrm{~h}$ with ethanolfree $\mathrm{CHCl}_{3}$ in a desiccator. Soils were extracted by shaking $1 \mathrm{~h}$ in $25 \mathrm{ml}$ solution of $0.5 \mathrm{M}$ $\mathrm{K}_{2} \mathrm{SO}_{4}$ and then filtered. Non-fumigated samples were processed in parallel. Total extractable organic $\mathrm{C}$ and $\mathrm{N}$ were analysed with a TOC-N analyser (Shimadzu, Kyoto, Japan). Extractable $\mathrm{C}$ in the non-fumigated samples was assumed to represent dissolved organic carbon (DOC). Microbial biomass $\mathrm{C}$ and $\mathrm{N}$ were calculated as the difference between fumigated and nonfumigated samples, which were used also to calculate microbial $\mathrm{C}: \mathrm{N}$ ratio. Microbial biomass C was corrected by dividing extractable $\mathrm{C}$ with a factor of 0.45 (Beck et al., 1997), N with a factor of 0.54 (Brookes, Landman, Pruden, \& Jenkinson, 1985).

\subsection{Basal respiration}

262 Basal respiration of the rewetted samples was measured with the MicroResp ${ }^{\mathrm{TM}}$ kit (Campbell, Chapman, Cameron, Davidson, \& Potts, 2003). Three analytical replicates of $0.5 \mathrm{~g}$ for each field replicate were taken from the incubation jars after rewetting and incubated in 96 deepwell plate in parallel to the incubation in jars. Soil was kept moist by a moist paper towel fixed on the plate. Respiration was measured 1, 2, 4, 8, 15, 18, 24 and 31 days after rewetting using a MicroResp ${ }^{\mathrm{TM}}$ kit (Campbell et al., 2003). To remove residual $\mathrm{CO}_{2}$ in the wells, the plate was aerated with a fan before incubating for $6 \mathrm{~h}$ with the indicator plate on top (at 27 (Microplate reader BioTek SynergyMX) at $570 \mathrm{~nm}$. Absorption calibration was done by 
dissolving a known amount of $\mathrm{NaCO}_{3}$ with $1 \mathrm{M} \mathrm{HCl}$ in excess in closed jars with eight

272

273

274

275 microwells of the indicator plate for $6 \mathrm{~h}$ (Campbell et al., 2003).

Soil respiration was partitioned using a two-pool mixed-model to describe SOC mineralization kinetics (Bonde \& Lindberg, 1988). The first pool follows a first-order decomposition kinetics, while the second follows a zero-order kinetics, corresponding to the stabilized basal respiration:

$$
C \min =C_{l}\left(1-e^{-t k_{l}}\right)+B R t
$$

where $t$ is the time, $C \min$ is the cumulative $\mathrm{CO}_{2}$ mineralized to time $\mathrm{t}, C_{l}$ is the labile $\mathrm{C}$ pool released from sample preparation and re-wetting, $k_{l}$ is the decomposition constant of the labile pool and $B R$ is the basal respiration. The basal respiration of each field replicate was determined by fitting the model on the three analytical replicates. The metabolic quotient is the ratio of basal respiration over microbial biomass $\mathrm{C}$ ( $\mathrm{Cmic})$.

\subsection{Statistical analyses}

All statistical analyses were performed using the open source software R version 3.2.1 ( $R$ Core Team, 2016). One sampling point in WC and one in IZ were removed from all analyses due to very low $\delta^{13} \mathrm{C}$ signatures, probably resulting from the former presence of $\mathrm{C} 3$ bush at these exact sampling locations. We used a linear mixed-effects model approach ("Ime4" package), followed by Tukey HSD tests for post hoc pairwise comparisons, to test for the effects of management zones (FP, HP, IZ and WC) on soil parameters (bulk, C3 and C4 stocks, fine root biomass, net $\mathrm{C} 3$ stabilization, basal respiration, microbial biomass $\mathrm{C}$ and $\mathrm{C}: \mathrm{N}$ ratio, and metabolic quotient) at each soil depth $(0-10,10-20$ and $20-30 \mathrm{~cm})$ in the mature plantation (9-year old) with palm trees as random factor. Normal distribution of residuals and homogeneity of variance were tested by Shapiro and Levene tests, respectively, and data was log-transformed if necessary. Causal relationships between parameters (C stocks vs. age, C3 
stocks vs. fine roots) were assessed by linear regressions. Average $\mathrm{C}$ stocks at plot scale down to $30 \mathrm{~cm}$ depth were calculated using the relative surface area of each management zone. Associations among parameters were calculated using Pearson correlation. P-values were determined using the function cor.test.

A path analysis was performed to disentangle the direct and indirect effects of fine roots, soil microorganisms and nutrient application on the accumulation of oil palm-derived SOC by using the "lavaan" package (Rosseel, 2012). Based on the priori knowledge, we developed an initial conceptual model that was both consistent with our data and which made biological sense (Fig. S3). We first created five conceptual groups of measured variables, which represented i) nutrient application (measure of available $\mathrm{P}$ ), ii) fine roots $\mathrm{C}$ inputs (measure of fine roots biomass), iii) SOM quality (measure of $\mathrm{C}: \mathrm{N}$ ratio of $\mathrm{SOM}$ ), iv) SOC accumulation (measure of oil palm-derived SOC) and v) soil microorganism effects. As a proxy for the microbial effect, we used the score of each sample on the first axis $(\mathrm{PC} 1=68$ $\%$ ) of a principal component analysis (PCA) including all microbial related variables (soil basal respiration, metabolic quotient, Nmic, Cmic, microbial C:N ratio) (Fig. S4). The conceptual model hypothesized that fine roots biomass and microbial activity have a direct impact on oil-palm SOC accumulation. Both might be affected by nutrient application. Additionally, microbial activity would be directly affected by root density through the amount of rhizodeposition and indirectly by changing organic matter quality. Finally, P availability could have a direct effect on microorganisms and SOM quality by changing the resources'

316 stoichiometry in the soil. Pedoclimatic factors affecting SOC stabilization (e.g. soil mineralogy) were not specified in the model because they are identical between zones and cannot be modified by management. The adequacy of the model was determined by nonsignificant differences between the predicted and observed covariance matrices $(\chi 2$ tests, $p>$ 0.05), low root mean squared error of approximation index (RMSEA $<0.1$ ), high Tucker- 
Lewis index (TLI > 0.90) and high comparative fit index (CFI > 0.90) (Grace, 2006; Rosseel, 2012).

\section{RESULTS}

\subsection{Soil organic carbon stocks and origin}

Observations done on the 9-year old plantation showed lower soil C stocks compared to the native savanna grasslands (Fig. 2). On average, $1.0 \pm 0.2 \mathrm{~kg} \mathrm{C} \mathrm{m}^{-2}$ was lost down to $30 \mathrm{~cm}$ depth, considering the relative area of each management zone. However, spatial SOC distribution in the mature oil palm plantation depended on management zones. Soil C losses during that period of time in the top $10 \mathrm{~cm}$ under frond piles and, to a lesser extent, under weeded circles were lower than $\mathrm{C}$ losses in harvest paths and interzones (Fig. 2). This trend was similar down to $30 \mathrm{~cm}$ depth but the differences were not significant below $10 \mathrm{~cm}$ depth.

Differences in SOC stocks between management zones arose mainly from a higher accumulation of oil palm-derived SOC (C3-derived) under frond piles and weeded circles (Fig. 2). Oil palm-derived SOC after 9 years already accounted for between $27 \%$ (IZ) and $45 \%$ (FP and WC) of the total SOC stock in the top $10 \mathrm{~cm}$, where differences between zones were highest. Below $20 \mathrm{~cm}$ depth, the contribution of oil palm-derived SOC dropped, accounting for $2 \%$ (IZ) and maximum $12 \%$ (WC) of the total SOC stocks. The amount of savanna-derived SOC (C4-derived) remaining after 9 years was lower in the top $10 \mathrm{~cm}$ than between 10-20 cm depth, indicating a faster decomposition of this $\mathrm{C}$ pool in the top soil compared to deeper soil layers. Nonetheless, management zones had little influence on the decomposition rates of savanna-derived SOC, except in 10-20 cm depth under weeded circles

344 where more $\mathrm{C}$ was lost than under frond piles. A similar trend was observed in the top $10 \mathrm{~cm}$ that explains why total SOC under weeded circles was intermediate as compared to frond 
piles and harvest paths, despite the high amount of oil palm-derived SOC stabilized under weeded circles.

\subsection{Root development and $C$ inputs}

350 Oil palm fine roots were first observed at $4.5 \mathrm{~m}$ away from palm trees in two out of the five 351 investigated palms in the 4-year old plantations (Fig. S2). This indicates that oil palm rooting systems from adjacent palms started to overlap at that age, but root biomass at $4.5 \mathrm{~m}$ was still very low. Fine root biomass under weeded circles increased constantly during 9 years (Fig. 3a). At the age of 9 years, roots were observed in all management zones but root growth was strongly enhanced under frond piles, reaching the same fine root biomass as under weeded circles in only 5 years, well above fine root biomass in the interzones and harvest paths (Fig. 3a).

Oil palm-derived SOC under weeded circles was highly correlated with fine root biomass (Fig. 3b). Oil palm-derived SOC stocks corresponded to $70 \pm 5 \%$ of fine root biomass stocks (slope $=0.70, \mathrm{R}^{2}=0.80$ ) at the time of measurement, independently of soil depth and plantation age. This percentage was relatively constant between the three soil depths; from $62 \pm 10 \%$ in the top $10 \mathrm{~cm}$ to $50 \pm 11 \%$ between $20-30 \mathrm{~cm}$ depth (Table 1 ). Oil palm-derived SOC accumulation per year was 3 to 4 times faster in the top soil $10 \mathrm{~cm}$ than in the underlying layers (Table 1).

While oil palm-derived SOC in the weeded circle was accumulating from the beginning of the plantation, root biomass was measured at fixed time points. Oil palm fine root biomass was integrated over the whole duration of the plantation to calculate the cumulative fine roots biomass for each year and soil depth under weeded circles. Accordingly, oil palm-derived SOC accumulation corresponded to $14 \pm 2 \%, 11 \pm 2 \%$ and $11 \pm 1 \%$ of the cumulated fine roots biomass stocks under weeded circles at 0-10, 10-20 and 20-30 cm depth, respectively (Table 
1). Since soil depth had little impact on the relationship between oil palm-derived SOC and

372

373

374 fine root biomass, differences in oil palm-derived SOC stabilization rates between depths were mainly related to differences in fine root biomass. The linear relationship across age showed that the proportion of oil-palm derived SOC stabilizing per amount of fine roots present in the plantation remains constant at least during 9 years (Fig. 3b).

Oil palm derived-SOC and fine root biomass were similar under frond piles and weeded circles in the top $10 \mathrm{~cm}$ in the 9-year old plantation (Fig. 3a). However, fine roots appeared at $4.5 \mathrm{~m}$ away from palms 4 years later than under weeded circles. To remove the effects of root density and duration of C inputs between zones, oil palm-derived SOC stocks were also divided by the cumulative roots biomass stocks and compared between management zones (Fig. 4).

After this normalization to the amount of fine root biomass, the stabilization of oil palmderived SOC was similar between frond piles and interzones, two zones receiving the same amount of mineral fertilizers and sampled at the same distance to the tree. Consequently, only little $\mathrm{C}$ from the large amount of $\mathrm{C}$ present in dead fronds is eventually stabilized in SOC. The stabilization of oil palm-derived SOC was lower under weeded circles, the zone receiving the largest amount of mineral fertilizer, than under harvest paths, the only zone experiencing no direct application of mineral fertilizers.

\subsection{Soil microorganisms and fertility}

Microbial activity (basal respiration and metabolic quotient) and biomass (microbial biomass $\mathrm{C}$ and microbial $\mathrm{C}: \mathrm{N}$ ratio) parameters were similar under frond piles and weeded circles (Fig. 5). In these two zones, the same amount of microbial biomass respired more $\mathrm{C}$ compared to harvest paths and interzones. Consequently, the metabolic quotient was highest under frond piles and weeded circles. 

the other zones, as expected by the higher fertilization application in that zone. Weeded circles also had the lowest amount of $\mathrm{K}_{2} \mathrm{SO}_{4}$-extractable $\mathrm{C}$ (DOC) despite high SOC content. (Table S1). Between the three zones (HP, IZ and FP) located at the same distance to the palm trees but varying in their management, $\mathrm{P}$ availability was two times lower in harvest paths $(11.1 \pm$ $0.3 \mu \mathrm{g} \mathrm{g}^{-1}$ ) as compared to frond piles, but well above the $\mathrm{P}$ availability in native savanna sites $\left(2.2 \pm 0.3 \mu \mathrm{g} \mathrm{g}^{-1}\right)$, despite the absence of direct fertilization. The DOC amount was similar between the three zones and the $\mathrm{C}: \mathrm{N}$ ratio was 1 unit higher under frond piles, indicating that only small change in SOC quality occurred between management zones.

\subsection{Drivers of the accumulation of oil palm-derived SOC}

In the three zones located at the same distance to the palm trees (HP, IZ and FP), oil palmderived SOC stocks (C3) were highly correlated with fine root biomass $(r=0.82)$, as well as to most microbial parameters, the amount of soil organic matter ( $\mathrm{C}$ and $\mathrm{N}$ contents) and available P (Fig. 6). The basal respiration, the metabolic quotient and the microbial biomass $\mathrm{N}$ increased with higher oil palm-derived SOC but not with total $\mathrm{C}$ content, underlying the role of fresh organic $\mathrm{C}$ to maintain microbial activity. By contrast, higher $\mathrm{C}: \mathrm{N}$ ratio in microbial biomass and, to a lesser extent, higher microbial biomass were associated to less oil palm-derived SOC and less fine roots biomass but with more savanna-derived SOC remaining after conversion to oil palm.

A path analysis was performed to disentangle the direct and indirect effects of fine roots, soil microorganisms and nutrient availability on the accumulation of oil palm-derived SOC at $4.5 \mathrm{~m}$ away from palm trees in the 9-year old plantation. Because of the high association among all microbial parameters (Fig. 6), the scores of each sample on the first axis (PC1 = 68 
used as a proxy for soil microorganisms in the path analysis (Fig. S4). The fitting parameters

422

423

424

425

426

427

428

429

430

431

432

433

434

435

436

437

438

439

440

441

442

443

444

445

of the model were good $\left(\mathrm{P} \chi^{2}=0.33, \mathrm{RMSEA}=0.09, \mathrm{TLI}=0.97, \mathrm{CFI}=0.99\right)$, and the model explained $71 \%$ of the variance in oil palm-derived SOC (Fig. 7). Fine root biomass was strongly influenced by nutrient availability (available P) and was an important driver of microbial properties (i.e. increase in microbial biomass $\mathrm{N}$, basal respiration, specific respiration and metabolic quotient and, in the opposite, decrease of microbial biomass $\mathrm{C}$ and $\mathrm{C}: \mathrm{N}$ ratio - see also Fig. 6). By contrast, nutrient availability had only a marginal ( $p=0.09)$ and opposite effect on soil microorganisms. While fine root biomass influenced SOM quality (C:N ratio), microorganisms were not affected by SOM quality. The direct effect of fine roots on oil palm-derived SOC stabilization was 2.8 times stronger than the marginal effect $(p=$ 0.06) of soil microorganisms. Accordingly, nutrient availability had an important indirect impact on the accumulation of oil palm-derived SOC by favouring root development and thereby $\mathrm{C}$ inputs without enhancing SOC mineralization.

\section{DISCUSSION}

\subsection{Drivers of SOC stabilization}

Soil organic $\mathrm{C}$ stocks strongly varied depending on the management zones of the plantation. Specific management impacted the amount of new oil palm $\mathrm{C}$ input and its stabilization into SOC but had little effect on the decomposition rate of old savanna-derived SOC (Fig. 2).

Carbon stabilization was mainly driven by $\mathrm{C}$ inputs from fine roots rather than by changes in C outputs from microbial mineralization (Fig. 7). The relationship between fine roots and oil palm derived SOC remained weakly affected by soil depth, plantation age and management zones (Table 1, Fig. 3 and 4). Fine root biomass was a good proxy for soil belowground C inputs. Oil palm fine roots absorb nutrient and water, and therefore have definite growth and 
446 short-term self-pruning. In contrast, coarse roots, which have the function of conduction, have 447 indefinite growth and long term self-pruning (Jourdan, Michaux-Ferrière, \& Perbal, 2000; 448 Jourdan \& Rey, 1997). The relationship between cumulated fine root biomass and oil-palm 449 derived SOC stocks would not remain constant once stocks reach equilibrium. The 450 relationship, however, was linear (Fig. 3), indicating that SOC stocks were still far from 451 equilibrium after 9 years of cultivation and that oil palm-derived SOC will continue to 452 increase.

Microbial metabolism and biomass were strongly affected by fine roots. Higher organic

$454 \mathrm{C}$ availability in terms of oil palm-derived SOC and C inputs under frond piles and in the 455 weeded circle were associated with microbial communities characterized by a high 456 mineralization activity but of low efficiency - the so termed $r$ strategy (Loeppmann, 457 Blagodatskaya, Pausch, \& Kuzyakov, 2016). The high metabolic quotient results from either 458 a low $\mathrm{C}$ use efficiency or a high microbial biomass turnover. By contrast, zones with low $\mathrm{C}$ 459 availability such as the harvest path and the interzones were associated with microbial 460 communities more efficient to maintain their biomass despite lower mineralization rates. 461 Their lower metabolic quotients and their higher C:N ratios suggest that the scarcity of $\mathrm{C}$ 462 increased the proportion of $\mathrm{K}$ strategists and fungi within microbial communities (Mouginot et al., 2014; Six, Frey, Thiet, \& Batten, 2006). While the main effect of nutrient availability 464 on microbial communities was indirect by increasing roots $\mathrm{C}$ inputs, it tended to have also a 465 minor direct but contrasting effect on microbial communities. Lower $\mathrm{C}$ to nutrients ratio 466 favours high $\mathrm{C}$ use efficiency of microorganisms, which would explain the larger microbial 467 biomass in interzones despite the low microbial activity and root density (Sinsabaugh, 468 Manzoni, Moorhead, \& Richter, 2013). Nonetheless, management impacts on microbial 469 communities and their resource consumption strategies levelled-off resulting in similar 470 fraction of SOC mineralized in all management zones. Weeded circles were the only area of 
the plantation showing slightly lower net SOC stabilization and savanna-derived SOC stocks

472 (Fig. 2 and 4). The very high amount of fertilizer applied already in the early stage of the plantation might have slightly fastened SOC turnover. Nonetheless, management effects were small in regards to the 10-fold increase of $\mathrm{P}$ availability in this zone as compared to the rest of the plantation. The fact that nutrient availability had little impact on the SOC mineralization and stabilization indicates that microorganisms were mostly C-limited. Indeed, soils were depleted in SOC and the whole surface area of the plantations, even areas not directly fertilized, experienced an increase in $\mathrm{P}$ availability as compared to native savannas.

In summary, management and its impact on soil belowground $\mathrm{C}$ inputs and nutrient availability did not lead to priming of recalcitrant SOC nor to faster turnover of fresh organic SOC, except around palms in the weeded circles. Hence, SOC distribution was not driven by an altered decomposition of SOC pools but by different rates of fine root growth and the resulting soil $\mathrm{C}$ inputs depending on management.

\subsection{Drivers of soil C inputs}

Oil palm rooting system follows a relatively rigid and genetically determined development (Jourdan et al., 2000; Jourdan \& Rey, 1997). Primary lateral roots start to grow one year after germination at a rate of $3 \mathrm{~mm} \mathrm{~d}^{-1}$, confirming that roots of palms, which are planted a year after germination, reach $4.5 \mathrm{~m}$ in the fourth year of a plantation (Jourdan \& Rey, 1997). Nevertheless, root development showed plasticity, reacting to management as shown by the fast development of fine roots under frond piles. Root development is generally enhanced in nutrients-rich zones (Hodge, 2004). Phosphorous availability was an important driver of root development, favoring soil $\mathrm{C}$ inputs from fine roots, and consequently the accumulation of new SOC (Fig. 7). Its distribution did not exactly reflect the pattern of fertilizer application (Table S1). Despite no direct fertilization applications, harvest paths were enriched in 
available $\mathrm{P}$ as compared to the reference savanna sites and only frond piles exhibited a significantly higher $\mathrm{P}$ availability. This discrepancy may result from the initial soil preparation with dolomite and phosphate rocks and seems to be maintained over time by the recycling of organic $\mathrm{P}$ inputs from rhizodeposition, root turnover, and frond mineralization. The positive impact of frond piles on root development is likely not limited to $\mathrm{P}$ availability.

501 Fronds piles increase the availability of major cations (Law, Husni, Ahmed, \& Haniff Harun, 2009). Similarly, it was shown that the application of empty fruit bunches on the surface increases soil moisture (Tao, Slade, Willis, Caliman, \& Snaddon, 2016) and roots development (Kheong, Rahman, Musa, \& Hussein, 2010). The positive impact of frond piles on SOC stocks has been previously reported (Haron, Brookes, Anderson, \& Zakaria, 1998; Law et al., 2009) but authors have already highlighted the small increase of SOC stocks given the huge amount of frond's biomass $\mathrm{C}$ concentrated on a small surface area $\left(2-3 \mathrm{~kg} \mathrm{C} \mathrm{m}^{-2} \mathrm{yr}^{-}\right.$

${ }^{1}$ in frond piles). It was suggested that fronds were mineralized mostly aboveground with little contribution to SOC (Haron et al., 1998). Our findings confirm this hypothesis and indicate that the positive impacts of frond piles arise more from the improvement of soil conditions (likely nutrient availability, humidity, protection from erosion) that favours root growth than from their role as a $\mathrm{C}$ source.

\subsection{Increasing SOC stocks}

515 Soil organic C stabilization depends on belowground C inputs and not on the management 516 induced variation of SOC mineralization rates (Fig. 7). This field evidence-based finding is similar to the conclusion of a modelling study on arable cropping system in temperate zones

518 (Autret et al., 2016). Soil C inputs should be enhanced to increase soil C sequestration in oil palm plantations. The current management practice that consist in piling dead fronds, however, is not efficient to integrate the fronds' organic matter into the soil. This can be 
explained by several mechanisms. First, organic matter quality in fronds is low due to high C to nutrient ratios (Yusuyin et al., 2015). This decreases the $\mathrm{C}$ use efficiency of microorganisms. Second, bioturbation from soil fauna is limited as indicated by a sharp transition between decomposing fronds and the soil surface observed in the field. Soil fauna abundance, especially of earthworms, and biogenic macroaggregates are lower in oil palm plantations as compared to native savanna and in improved pastures (Lavelle et al., 2014).

527 Consequently, fronds' organic matter does not benefit from the protection mechanisms that minerals would provide if it was integrated into the soils by fauna activity (Schmidt et al., 2011). Application of composted mill residues would be a solution to decrease $\mathrm{C}$ to nutrient ratios of litter and improve the integration of organic matter into the soil by favouring soil fauna activity, humification and mineral protection.

The availability of organic residues from the palm oil production chain that could be applied in plantations, however, is limited. Leguminous cover crops, as already implemented in the younger plantations, are an alternative to increase aboveground and belowground $\mathrm{C}$ and

$535 \mathrm{~N}$ inputs. Enhancing root growth by mimicking the effects of frond piles is a promising 536 solution to increase SOC if palms have plasticity to allocate more $\mathrm{C}$ to their rooting system when soil conditions are favourable or if palm varieties are developed for that purpose. Oil palm fronds could be spread on larger surface area or mixed with other residues, such as empty fruit bunched or fibers, to make a mulch. Even solutions not based on organic matter 540 that would limit soil evaporation, retain nutrients, limit run-offs and erosion might improve 541 root development. Future research should address whether SOC stocks eventually recover to 542 initial SOC levels. Ensuring long-term soil fertility in oil palm plantations is fundamental to avoid a conversion of natural ecosystem constrained by soil degradation in older plantation.

544 The benefits from increasing SOC in terms of climate change mitigation would cascade far 545 beyond the amount of $\mathrm{C}$ sequestrated in the soil because of the gain in soil fertility. 


\section{ACKNOWLEDGEMENTS}

548 This study was financed by the Swiss National Science Foundation ( $\mathrm{r} 4 \mathrm{~d}$ - Ecosystems) "Oil

549 Palm Adaptive Landscape" no. 152019. Contribution of YK was supported by the Russian

550 Science Foundation (project No. 18-14-00362). We thank the owners and agronomists of the

551 Palmeras Sillatava and Samani Italcol de Occidente for granting us access to their land and 552 for their logistical support.

553

\section{CONFLICT OF INTEREST STATEMENT}

555 The authors declare no conflict of interest.

556

557

\section{REFERENCES}

558

559

560

561

562

563

564

Amundson, R., Berhe, a. a., Hopmans, J. W., Olson, C., Sztein, a. E., \& Sparks, D. L. (2015). Soil and human security in the 21st century. Science, 348, 1261071-1261071. https://doi.org/10.1126/science.1261071

Autret, B., Mary, B., Chenu, C., Balabane, M., Girardin, C., Bertrand, M., ... Beaudoin, N. (2016). Alternative arable cropping systems : A key to increase soil organic carbon storage? Results from a 16 year fi eld experiment. Agriculture, Ecosystems and Environment, 232, 150-164. https://doi.org/10.1016/j.agee.2016.07.008

Balesdent, J., \& Mariotti, A. (1987). Natural 13C abundance as a tracer for studies of soil organic matter dynamics. Soil Biology and Biochemistry, 19, 25-30.

Beck, T., Joergensen, R. G., Kandeler, E., Makeschin, F., Nuss, E., Oberholzer, H. R., \& Scheu, S. (1997). An inter-laboratory comparison of ten different ways of measuring soil microbial biomass C. Soil Biology and Biochemistry, 29, 1023-1032. https://doi.org/10.1016/s0038-0717(97)00030-8 
Bonde, T. A., \& Lindberg, T. (1988). Nitrogen Mineralization Kinetics in Soil During Longterm Aerobic Laboratory Incubations: A Case Study. Journal of Environment Quality, 17, 414-417. https://doi.org/10.2134/jeq1988.00472425001700030011x

Bray, R. H., \& Kurtz, L. T. (1945). Determination of total, organic, and available forms of phosphorous in soils. Soil Science, 59, 39-45. https://doi.org/10.1097/00010694194501000-00006

Brookes, P. C., Landman, A., Pruden, G., \& Jenkinson, D. S. (1985). Chloroform fumigation and the release of soil-nitrogen - a rapid direct extraction method to measure microbial biomass nitrogen in soil. Soil Biology and Biochemistry, 17, 837-842. https://doi.org/10.1016/0038-0717(85)90144-0

Campbell, C. D., Chapman, S. J., Cameron, C. M., Davidson, M. S., \& Potts, J. M. (2003). A rapid microtiter plate method to measure carbon dioxide evolved from carbon substrate amendments so as to determine the physiological profiles of soil microbial communities by using whole soil. Applied and Environmental Microbiology, 69, 3593-3599. https://doi.org/10.1128/aem.69.6.3593-3599.2003

Finn, D., Page, K., Catton, K., Kienzle, M., Robertson, F., Armstrong, R., \& Dalal, R. (2016). Ecological stoichiometry controls the transformation and retention of plant-derived organic matter to humus in response to nitrogen fertilisation. Soil Biology and Biochemistry, 99, 117-127. https://doi.org/10.1016/j.soilbio.2016.05.006

Frazão, L. A., Paustian, K., Pellegrino Cerri, C. E., \& Cerri, C. C. (2013). Soil carbon stocks and changes after oil palm introduction in the Brazilian Amazon. GCB Bioenergy, 5, 384-390. https://doi.org/10.1111/j.1757-1707.2012.01196.x

Ghimire, R., Lamichhane, S., Acharya, B. S., Bista, P., \& Sainju, U. M. (2017). Tillage, crop residue, and nutrient management effects on soil organic carbon in rice-based cropping systems: A review. Journal of Integrative Agriculture, 16(1), 1-15. 
Goodrick, I., Nelson, P., Nake, S., Webb, M., Bird, M., \& Huth, N. (2015). Tree-scale spatial variability of soil carbon cycling in a mature oil palm plantation. Soil Research, 54, 397406. https://doi.org/10.1071/SR15211

Grace, J. B. (2006). Structural equation modeling and natural systems. Cambridge, UK: Cambridge University Press. https://doi.org/10.1017/CBO9780511617799

Guillaume, T., Damris, M., \& Kuzyakov, Y. (2015). Losses of soil carbon by converting 603 tropical forest to plantations: Erosion and decomposition estimated by $\delta 13$ C. Global Change Biology, 21, 3548-3560. https://doi.org/10.1111/gcb.12907

605

606

607

608

609

610

611

612

613

614

615

616

617

618

619

620

Guillaume, T., Holtkamp, A. M., Damris, M., Brümmer, B., \& Kuzyakov, Y. (2016). Soil degradation in oil palm and rubber plantations under land resource scarcity. Agriculture, Ecosystems \& Environment, 232, 110-118. https://doi.org/10.1016/j.agee.2016.07.002

Guillaume, T., Kotowska, M. M., Hertel, D., Knohl, A., Krashevska, V., Murtilaksono, K., ... Kuzyakov, Y. (2018). Carbon Costs and Benefits of Indonesian Rainforest Conversion to Plantations. Nature Communications, 9, 2388. https://doi.org/10.1038/s41467-018-04755-y

Haddaway, N. R., Hedlund, K., Jackson, L. E., Kätterer, T., Lugato, E., Thomsen, I. K., ... Isberg, P. E. (2017). How does tillage intensity affect soil organic carbon? A systematic review. Environmental Evidence, 6(1), 1-48. https://doi.org/10.1186/s13750-017-01089

Haron, K., Brookes, P. C., Anderson, J. M., \& Zakaria, Z. Z. (1998). Microbial biomass and soil organic matter dynamics in oil palm (Elaeis guineensis jacq.) plantations, West Malaysia. Soil Biology and Biochemistry, 30, 547-552. https://doi.org/10.1016/S00380717(97)00217-4

Hodge, A. (2004). The plastic plant: Root responses to heterogeneous supplies of nutrients. 
IUSS Working Group WRB. (2014). World reference base for soil resources 2014. World

623

624

625

626

627

628

629

630

631

632

633

634

635

636

637

638

639

640

641

642

643

644

645

Soil Resources Reports (Vol. 106). FAO, Rome. Retrived from http://www.fao.org/3/i3794en/I3794en.pdf.

Jourdan, C., Michaux-Ferrière, N., \& Perbal, G. (2000). Root system architecture and gravitropism in the oil palm. Annals of Botany, 85, 861-868. https://doi.org/10.1006/anbo.2000.1148

Jourdan, C., \& Rey, H. (1997). Architecture and development of the oil-palm (Elaeis guineensis Jacq.) root system. Plant and Soil, 189, 33-48. https://doi.org/10.1023/A:1004290024473

Khasanah, N., van Noordwijk, M., Ningsih, H., \& Rahayu, S. (2015). Carbon neutral? No change in mineral soil carbon stock under oil palm plantations derived from forest or non-forest in Indonesia. Agriculture, Ecosystems \& Environment, 211, 195-206. https://doi.org/10.1016/j.agee.2015.06.009

Kheong, L. V., Rahman, Z. A., Musa, M. H., \& Hussein, A. (2010). Empty fruit bunch application and oil palm root proliferation. Journal of Oil Palm Research, 22, 750-757. Retrived from http://jopr.mpob.gov.my/wp-content/uploads/2013/09/joprv22april10Liew21.pdf

Kirkby, C. A., Richardson, A. E., Wade, L. J., Passioura, J. B., Batten, G. D., Blanchard, C., \& Kirkegaard, J. A. (2014). Nutrient availability limits carbon sequestration in arable soils. Soil Biology and Biochemistry, 68, 402-409. https://doi.org/10.1016/j.soilbio.2013.09.032

Kuzyakov, Y., Friedel, J. K., \& Stahr, K. (2000). Review of mechanisms and quantification of priming effects. Soil Biology and Biochemistry, 32, 1485-1498. https://doi.org/10.1016/s0038-0717(00)00084-5 
646 Lal, R. (2016). Beyond COP 21: Potential and challenges of the "4 per Thousand" initiative.

647

648

649

650

651

652

653

654

655

656

657

658

659

660

661

662

663

664

665

666

667

668

669

670

Journal of Soil and Water Conservation, 71, 20A-25A. https://doi.org/10.2489/jswc.71.1.20A

Lavelle, P., RodrIguez, N., Arguello, O., Bernal, J., Botero, C., Chaparro, P., ... Fonte, S. J. (2014). Soil ecosystem services and land use in the rapidly changing orinoco river basin of colombia. Agriculture, Ecosystems \& Environment, 185, 106-117. https://doi.org/10.1016/j.agee.2013.12.020

Law, M. C., Husni, M. H. A., Ahmed, O. H., \& Haniff Harun, M. (2009). Spatial variability of soil organic carbon in oil palm: a comparison between youg and mature stands. International Journal of Agricultural Research, 4, 402-417.

Loeppmann, S., Blagodatskaya, E., Pausch, J., \& Kuzyakov, Y. (2016). Substrate quality affects kinetics and catalytic efficiency of exo-enzymes in rhizosphere and detritusphere. Soil Biology and Biochemistry, 92, 111-118. https://doi.org/10.1016/j.soilbio.2015.09.020

Lorenz, K., \& Lal, R. (2018). Soil Carbon Stock. In Carbon Sequestration in Agricultural Ecosystems (pp. 39-136). Springer International Publishing. https://doi.org/10.1007/978-3-319-92318-5_2

Mouginot, C., Kawamura, R., Matulich, K. L., Berlemont, R., Allison, S. D., Amend, A. S., \& Martiny, A. C. (2014). Elemental stoichiometry of fungi and bacteria strains from grassland leaf litter. Soil Biology and Biochemistry, 76, 278-285. https://doi.org/10.1016/j.soilbio.2014.05.011

Pabst, H., Gerschlauer, F., Kiese, R., \& Kuzyakov, Y. (2016). Land Use and Precipitation Affect Organic and Microbial Carbon Stocks and the Specific Metabolic Quotient in Soils of Eleven Ecosystems of Mt. Kilimanjaro, Tanzania. Land Degradation \& Development, 27, 592-602. https://doi.org/10.1002/ldr.2406 
671 Pausch, J., \& Kuzyakov, Y. (2012). Soil organic carbon decomposition from recently added

672

673

674

675

676

677

678

679

680

681

682

683

684

685

686

687

688

689

690

691

692

693

694

695 and older sources estimated by $13 \mathrm{C}$ values of $\mathrm{CO} 2$ and organic matter. Soil Biology and Biochemistry, 55, 40-47. https://doi.org/10.1016/j.soilbio.2012.06.007

Pausch, J., \& Kuzyakov, Y. (2018). Carbon input by roots into the soil: Quantification of rhizodeposition from root to ecosystem scale. Global Change Biology, 24, 1-12. https://doi.org/10.1111/gcb.13850

Pausch, J., Tian, J., Riederer, M., \& Kuzyakov, Y. (2013). Estimation of rhizodeposition at field scale: Upscaling of a14C labeling study. Plant and Soil, 364, 273-285. https://doi.org/10.1007/s11104-012-1363-8

Qiao, N., Xu, X., Hu, Y., Blagodatskaya, E., Liu, Y., Schaefer, D., \& Kuzyakov, Y. (2016). Carbon and nitrogen additions induce distinct priming effects along an organic-matter decay continuum. Scientific Reports, 6, 19865. https://doi.org/10.1038/srep19865

Rahman, N., De Neergaard, A., Magid, J., Van De Ven, G. W. J., Giller, K. E., \& Bruun, T. B. (2018). Changes in soil organic carbon stocks after conversion from forest to oil palm plantations in Malaysian Borneo. Environmental Research Letters, 13, 105001. https://doi.org/10.1088/1748-9326/aade0f

Rippstein, G., Amézquita, E., Escobar, G., \& Grollier, C. (2001). Condiciones naturales de la sabana. In Agroecología y biodiversidad de las sabanas en los Llanos Orientales de Colombia (pp. 1-21). Cali, Colombia: Centro Internacional de Agricultura Tropical.

Rosseel, Y. (2012). lavaan: An R package for structural equation modelling. Journal of Statistical Software, 48, 1-36. https://doi.org/10.18637/jss.v048.i02

Schmidt, M. W. I., Torn, M. S., Abiven, S., Dittmar, T., Guggenberger, G., Janssens, I. a., ... Trumbore, S. E. (2011). Persistence of soil organic matter as an ecosystem property. Nature, 478, 49-56. https://doi.org/10.1038/nature10386

Sinsabaugh, R. L., Manzoni, S., Moorhead, D. L., \& Richter, A. (2013). Carbon use efficiency 
of microbial communities: Stoichiometry, methodology and modelling. Ecology Letters, 16, 930-939. https://doi.org/10.1111/ele.12113

Six, J., Frey, S. D., Thiet, R. K., \& Batten, K. M. (2006). Bacterial and Fungal Contributions to Carbon Sequestration in Agroecosystems. Soil Science Society of America Journal, 70, 555. https://doi.org/10.2136/sssaj2004.0347

Tao, H.-H., Slade, E. M., Willis, K. J., Caliman, J.-P., \& Snaddon, J. L. (2016). Effects of soil management practices on soil fauna feeding activity in an Indonesian oil palm plantation. Agriculture, Ecosystems \& Environment, 218, 133-140. https://doi.org/10.1016/j.agee.2015.11.012

Team, R. C. (2016). R: A language and environment for statistical computing. Vienna, Austria: R Foundation for Statistical Computing. Retrieved from https://www.rproject.org/

Vance, E. D., Brookes, P. C. \& Jenkinson, D. S. (1987). An extraction method for measuring soil microbial biomass C. Soil biology and Biochemistry, 19(6), 703-707. http://doi.org/10.1016/0038-0717(87)90052-6

Yusuyin, Y., Tan, N. P., Wong, M. K., Abdu, A. Bin, Iwasaki, K., \& Tanaka, S. (2015). Nutrient Status of Frond Heaps and the Underlying Soils at An 18-Year-Old Oil Palm Field in Central Pahang, Malaysia. Tropical Agriculture and Development, 59, 212-220. https://doi.org/10.11248/jsta.59.212

Zang, H., Wang, J., \& Kuzyakov, Y. (2016). N fertilization decreases soil organic matter decomposition in the rhizosphere. Applied Soil Ecology, 108, 47-53. https://doi.org/10.1016/j.apsoil.2016.07.021

Zech, W., Senesi, N., Guggenberger, G., Kaiser, K., Lehmann, J., Miano, T. M., ... Schroth, G. (1997). Factors controlling humification and mineralization of soil organic matter in the tropics. Geoderma, 79, 117-161. https://doi.org/10.1016/S0016-7061(97)00040-2 
722

723 Table 1. Oil palm-derived SOC stabilization under weeded circles at each depth depending 724 on time, fine root biomass in the plantation and fine root biomass cumulated since plantation 725 establishment (mean \pm SE). All linear regressions were significant at $\mathrm{p}<0.001$.

726

\begin{tabular}{|c|c|c|c|c|c|c|}
\hline \multirow{2}{*}{$\begin{array}{c}\text { Weeded circles } \\
\text { Depths } \\
\mathrm{cm}\end{array}$} & \multicolumn{2}{|c|}{$\begin{array}{l}\text { OP-derived SOC } \\
\text { per year }\end{array}$} & \multicolumn{2}{|c|}{$\begin{array}{l}\text { OP-derived SOC } \\
\text { per fine roots }\end{array}$} & \multicolumn{2}{|c|}{$\begin{array}{c}\text { OP-derived SOC } \\
\text { per cumulative fine roots }\end{array}$} \\
\hline & $g S O C m^{-2} y r^{-1}$ & $R^{2}$ & $g$ SOC $g^{-1}$ roots & $R^{2}$ & $g$ SOC $g^{-1}$ roots & $R^{2}$ \\
\hline $0-10(\mathrm{n}=14)$ & $54 \pm 6$ & 0.85 & $0.62 \pm 0.10$ & 0.76 & $0.14 \pm 0.02$ & 0.86 \\
\hline $10-20(\mathrm{n}=15)$ & $18 \pm 6$ & 0.55 & $0.53 \pm 0.11$ & 0.60 & $0.11 \pm 0.02$ & 0.59 \\
\hline $20-30(n=15)$ & $12 \pm 2$ & 0.75 & $0.50 \pm 0.11$ & 0.57 & $0.11 \pm 0.01$ & 0.80 \\
\hline
\end{tabular}

727

728 
Fig. 1. Management zones in a mature oil palm plantation. (a) Four management zones varying in terms of fertilization and aboveground C inputs. (b) Sampling points (red dots) in the 9-year old plantation. Frond piles and harvest paths are absent in the 2-and 4-year old plantations but two additional points (empty red dots) were sampled to assess palm root lateral extension

Fig. 2. Soil organic C stocks separated between oil palm-derived soil organic carbon (C3derived SOC) and savanna-derived SOC (C4-derived C) depending on management zones and soil depths after 9 years of oil palm cultivation on savanna grasslands. Mean values \pm SE are represented ( $\mathrm{n}=5$ for FP and HP, $\mathrm{n}=4$ for IZ and WC). FP, frond pile; HP, harvest path; IZ, interzone; WC, weeded circle. Letters indicate significant differences between management zones in total SOC (upper-case) and oil palm-derived SOC (black lower-case) and savanna-derived SOC (white lower-case). The red continuous line shows the original SOC level $( \pm$ SE) in savanna grasslands $(n=10)$. The difference between red line and the top of the stacked bars show the $\mathrm{C}$ losses over 9 years of oil palm cultivation

Fig. 3. Oil palm fine root development and oil palm-derived soil organic carbon (SOC) stocks. (a) Oil palm fine root development with plantation age in the top $10 \mathrm{~cm}$ under frond piles (FP), weeded circles (WC), harvest paths (HP), and interzones (IZ). Mean values \pm SE are represented ( $\mathrm{n}=5$ for FP and HP, $\mathrm{n}=4$ for IZ and WC). Letters indicate significant differences between management zones in the 9-year old plantation; (b) relationship between oil palmderived SOC (C3-SOC) and fine root biomass under weeded circles. Overall linear regression is indicated by the dashed line. Negative C3-SOC values result from the natural variation 
standard of reference sites around the mean $13 \mathrm{C}$ value when $\mathrm{C} 3-\mathrm{SOC}$ accumulation is very

755

756

757

758

759

760

761

762

763

764

765

766

767

768

769

770

771

772

773

774

775

776

777

778

low or absent. Negative data were not set to zero to avoid increasing artificially the mean of the respective depth and age and thus decreasing the overall slope of the relationship. The two large arrows show the opposite effects of the plantation time and soil depth on the amount of new $\mathrm{C}(\mathrm{C} 3)$ stabilized in soil

Fig. 4. Net oil-palm derived SOC (C3) stabilized per amount of cumulated fine root biomass in each management zone after 9 years. Different letters indicate significant differences between harvest paths (HP), interzones (IZ), frond piles (FP), and weeded circles (WC). Mean values \pm SE are represented ( $n=5$ for FP and HP, $n=4$ for IZ and WC)

Fig. 5. Relative effects of management zones on soil microorganisms in the 9-year old plantation: basal respiration, metabolic quotient, microbial biomass $\mathrm{C}$, and $\mathrm{C}: \mathrm{N}$ ratio of microbial biomass. Microbial variables in interzones (IZ), frond piles (FP), and weeded circles (WC) were normalized with their respective mean value in the harvest paths (HP), that is, the zone receiving neither $\mathrm{C}$ inputs nor nutrient applications. Specific respiration (basal respiration divided by $\mathrm{C}$ content) is not represented because the effect of management zone was not significant. Error bars represent SE ( $n=5$ for FP and HP, $n=4$ for IZ and WC). Letters indicate significant differences between management zones for each parameter

Fig. 6. Pearson correlation matrix among soil variables in the top $10 \mathrm{~cm}$. Correlation performed on samples collected in the three management zones located at $4.5 \mathrm{~m}$ away from palm trees (harvest paths, interzones, and frond piles). Variables are: basal respiration, specific respiration, metabolic quotient, oil palm-derived (C3), and savanna-derived (C4) SOC stocks, soil $\mathrm{C}$ and $\mathrm{N}$ contents $(\mathrm{C}, \mathrm{N})$, microbial biomass $\mathrm{C}$ and $\mathrm{N}(\mathrm{Cmic}$ and $\mathrm{Nmic}), \mathrm{C}: \mathrm{N}$ 
ratios of SOM $(\mathrm{CN}), \mathrm{K} 2 \mathrm{SO} 4$-extractable $\mathrm{C}(\mathrm{DOC})$, soil available $\mathrm{P}(\mathrm{P})$, and fine root biomass stocks (Fine roots). Only significant correlations are represented $(\mathrm{p}<.05, \mathrm{n}=14)$

781

782 Fig. 7. Drivers of oil palm-derived soil organic carbon (SOC) accumulation in the top $10 \mathrm{~cm}$ 783 of the three management zones located at $4.5 \mathrm{~m}$ away from palm trees (harvest paths, 784 interzones, and frond piles). Phosphorus availability was used as proxy for nutrient availability. Fine roots correspond to fine root biomass stocks. Scores of samples on the first axis $(68 \%)$ of a principal component analysis (PCA) of all microbially related variables were used as proxy for microbial effects. The $\mathrm{C}: \mathrm{N}$ ratio of SOM was used as proxy for soil organic matter quality. Solid arrows represent significant effects $(* \mathrm{p}<.05, * * * \mathrm{p}<.001, \mathrm{n}=14)$ and widths are proportional to the effect. Dashed arrows represent marginally effects $(p<.10)$. Non-significant relationships $(\mathrm{p}>.10)$ are not represented (nutrient availability to SOM quality and SOM quality to soil microorganisms) 
Fig. 1.

794

795

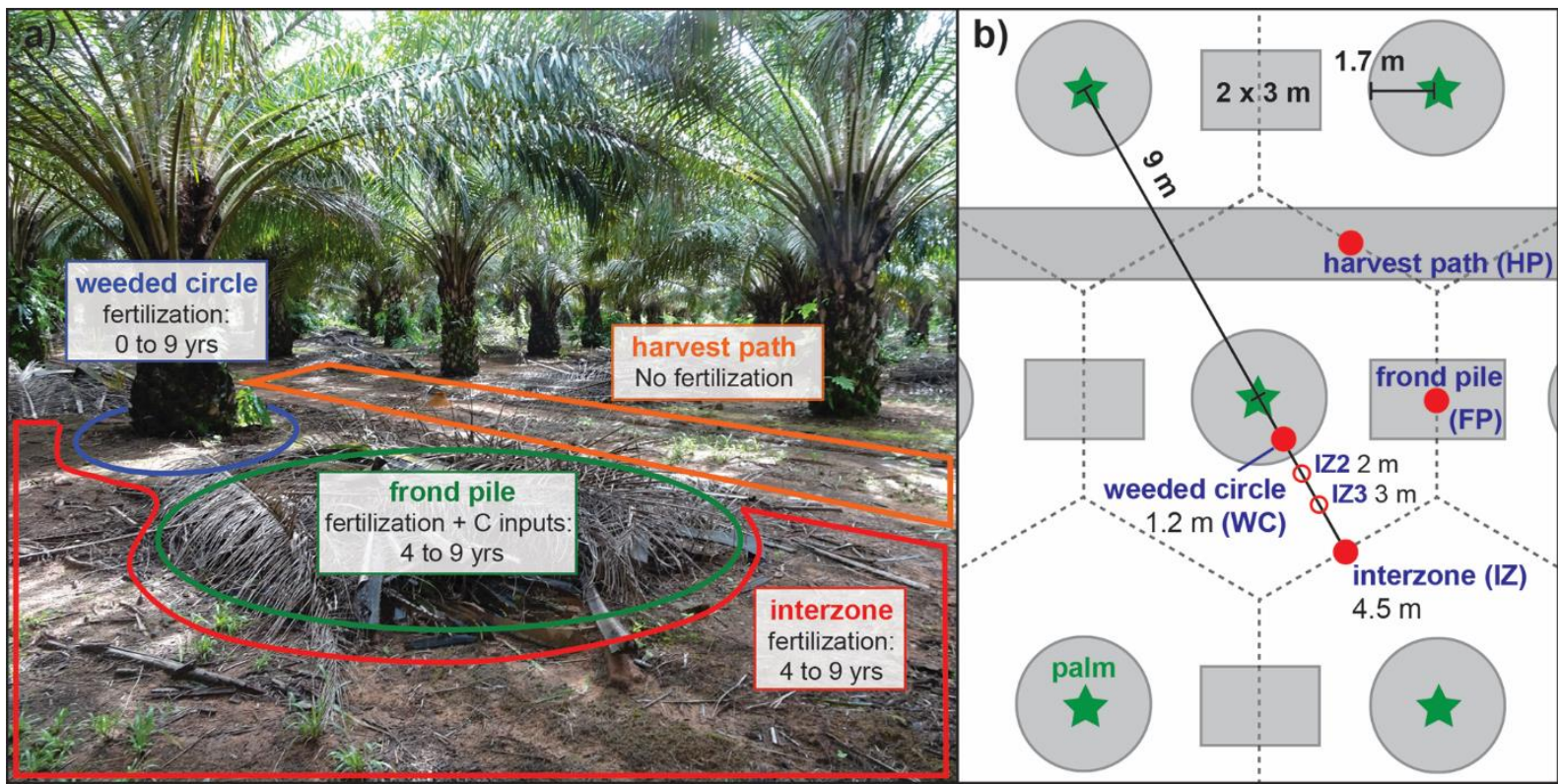

796 
Fig. 2.

798

799
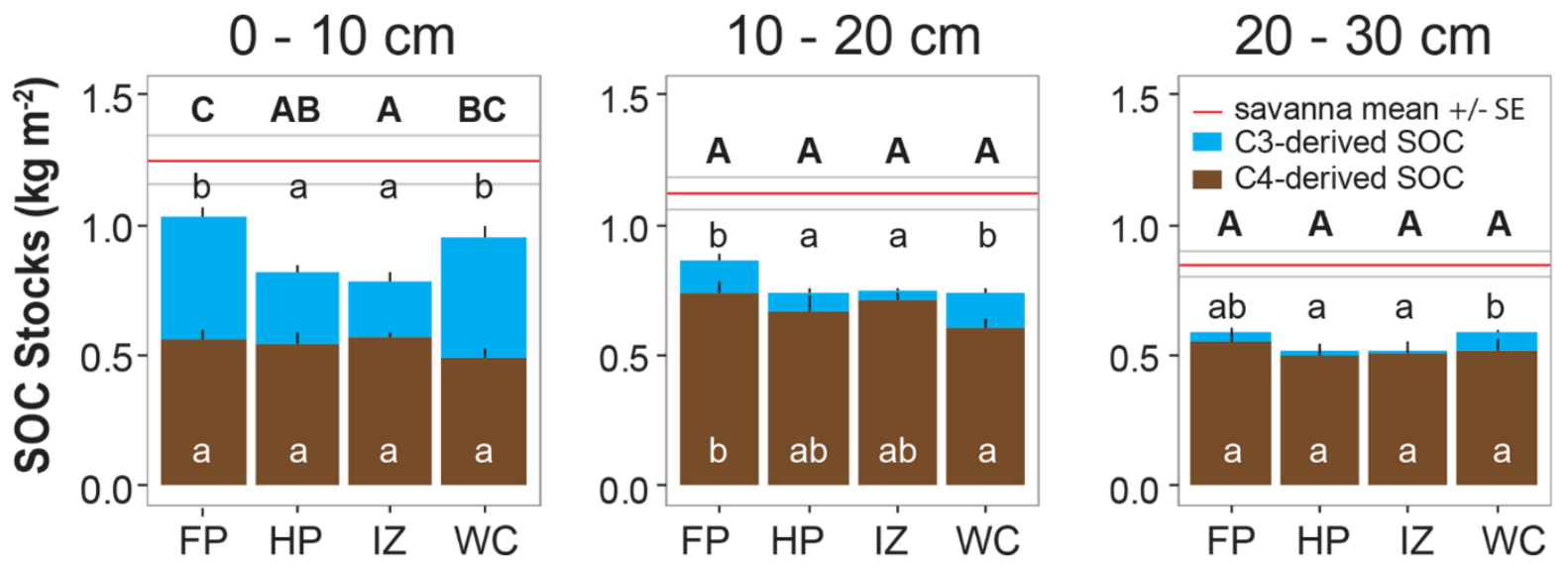

800 
801

Fig. 3.

802
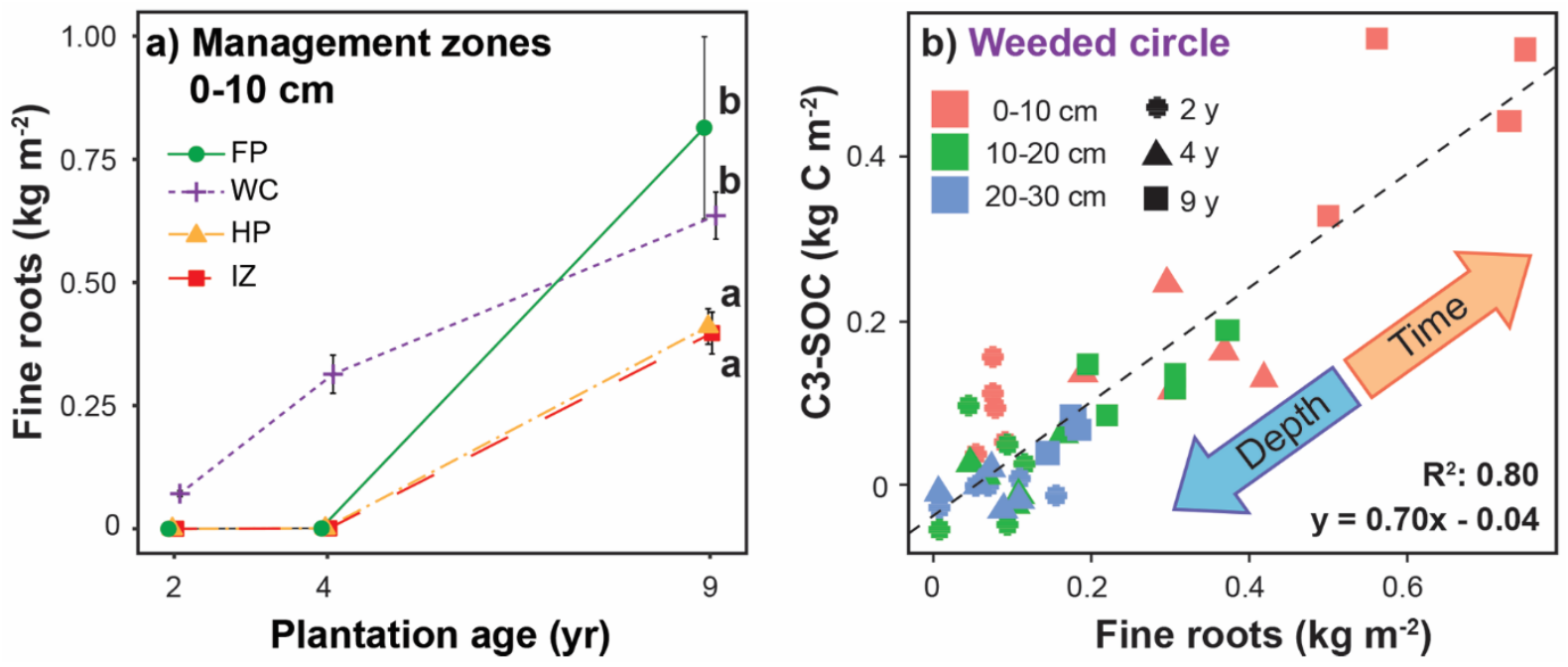

804 
$805 \quad$ Fig. 4.

806

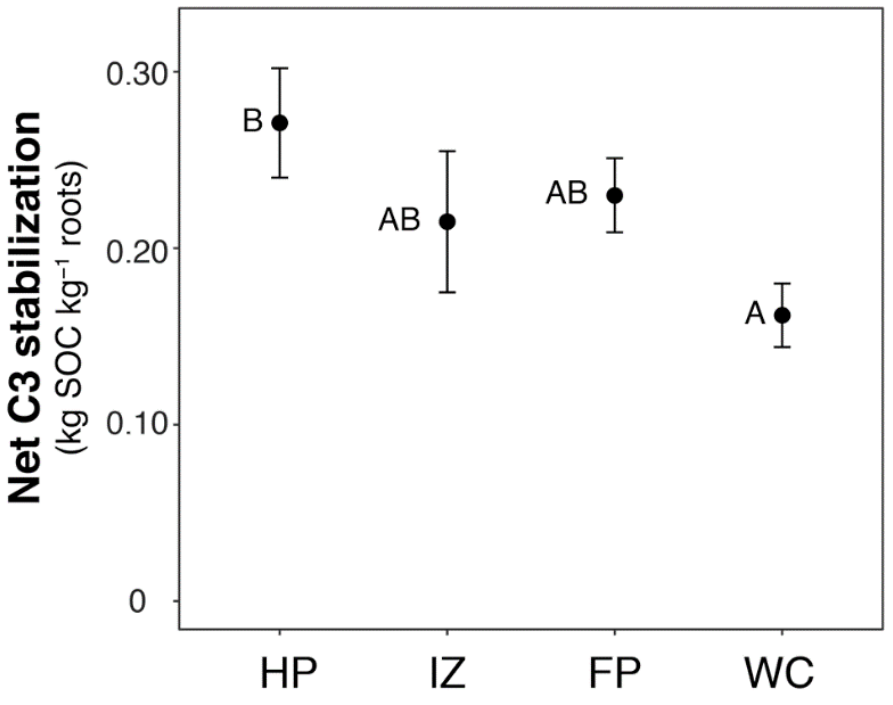

808 
809

Fig. 5.

810

811

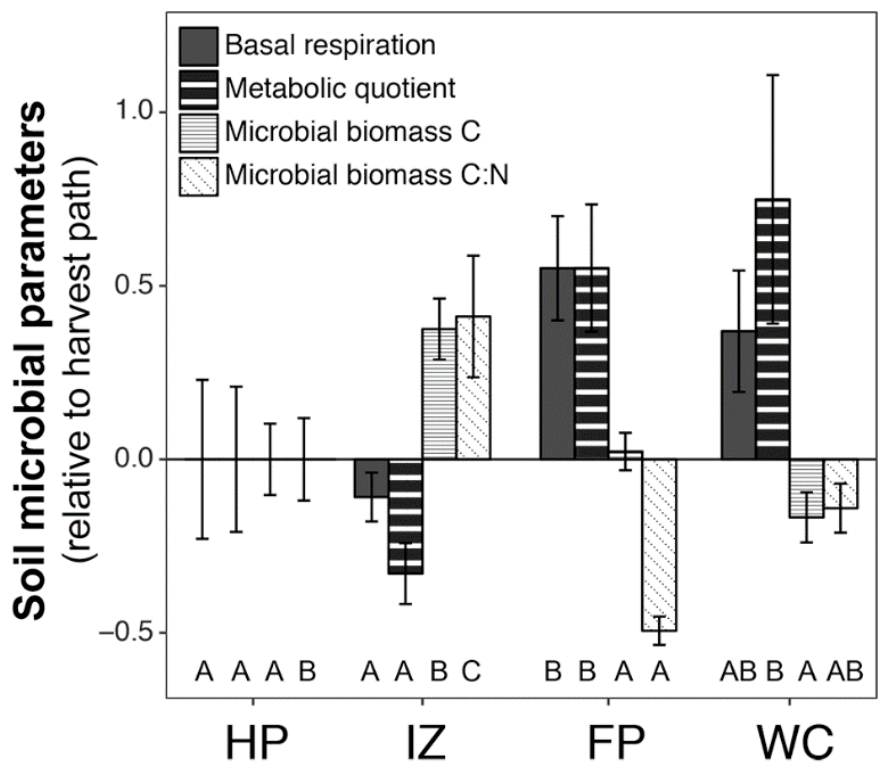

812 
$813 \quad$ Fig. 6.

814

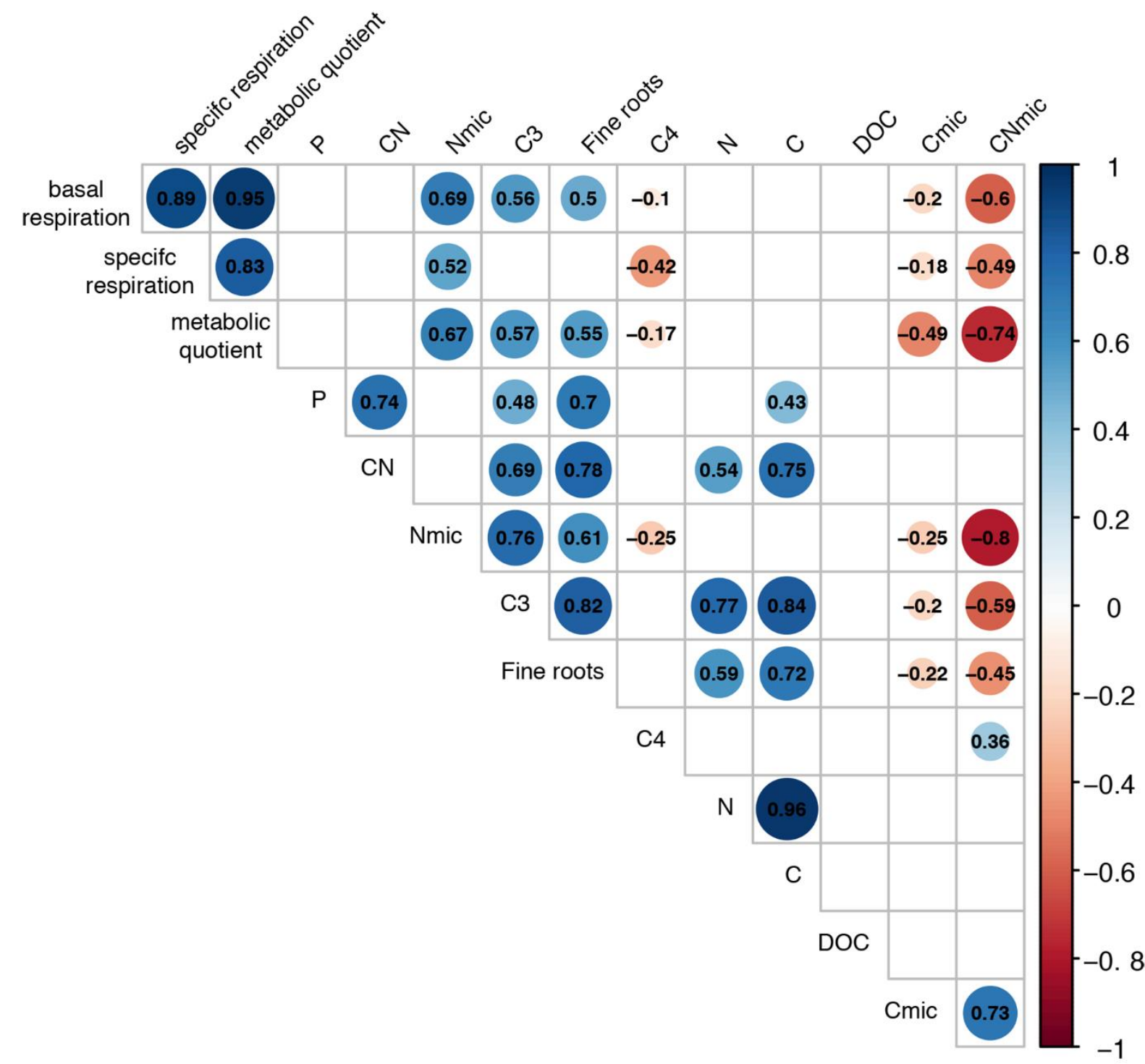

815

816 
$817 \quad$ Fig. 7.

818

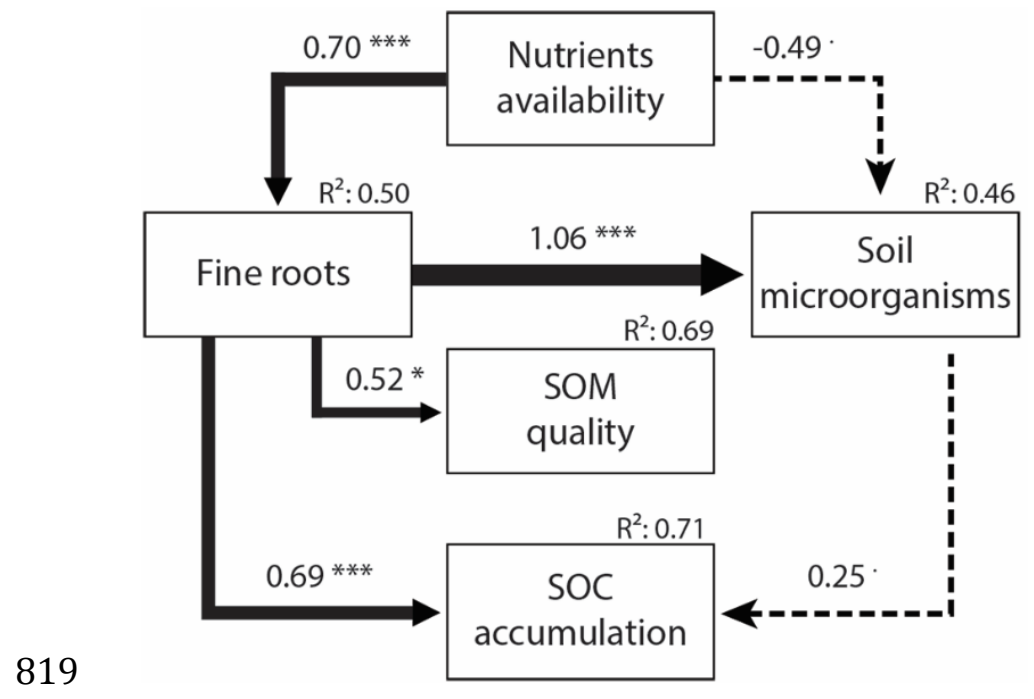

820 